\title{
Study on the Performance of Light Sources under Voltage Sag and the Compensation Method
}

\author{
Binbin $\mathrm{Li}^{1}$, Taiyun Zhu ${ }^{1}$, Dengfeng Cheng ${ }^{1}$, Wei Yang ${ }^{1}$, Yanguo $\mathrm{Ke}^{2}$, Sha $\mathrm{Luo}^{2}$, Shenglong $\mathrm{Zhu}^{1}, \mathrm{Yu}^{2}$ Tian and \\ Changwei ${ }^{1}$ Zhao
}

${ }^{1}$ State Grid Electric Power Research Institute of Anhui Electric Power Corporation, Hefei, 230022, China

${ }^{2}$ State Grid Anhui Electric Power Corporation, Hefei, 230022, China

\begin{abstract}
All kinds of light sources are sensitive to the power supply, which may be shut down when the grid voltage sag or cut off. It will take more than ten minutes for gas discharge lamps to restart due to their cold start features. In this paper, several typical light sources are selected to do voltage drop tests under different amplitude and phase angle, in which the performance of lamps are carried out. Then a compensation method is presented for HID lamps.
\end{abstract}

Keywords-gas discharge lamp; voltage sag; compensation device; drop amplitude; phase angle

\section{INTRODUCTION}

Voltage Sag refers to the phenomenon that RMS voltage declines from $90 \%$ to $10 \%$ of the rated voltage rapidly, with a typical duration from 0.5 to 30 cycles. Short circuit faults of transmission and distribution lines, transformer excitation and large-capacity induction motor starting may cause voltage sags with different phenomenon [1-4], which can be solved from system side [5]. This paper presents a compensation method from user side based on the study of performance of lamps under the voltage sag.

High-intensity discharge (HID) lamps such as sodium and metal halide lamps are voltage-sensitive loads. Lamps will sustain a little time before going out when power grid voltage drops or suddenly power off. And due to their cold start characteristics, it needs more than ten minutes to restart [6].

To fulfill the specific requirements of important political users for lighting load, a compensation device for HID lamps should be studied based on analysis of their characteristics under voltage sag to reach the 'Non-flicker' goal. When power grid voltage fluctuates or fails, the light sources should keep on till the emergency power supply starts operating to prevent restarting HID lamps.

In this paper, a voltage drop generating device is used to study the characteristics of typical lamps under voltage sag. Then a compensation method for the single HID lamp is proposed to avoid its going out.

\section{MEASUREMENT OF Light SOURCES' CHARACTERISTICS UNDER VOLTAGE SAG}

\section{A. The Set-up of the Measurement}

In this paper, a voltage drop generating device is applied to measuring typical lamps, whose schematic and principle shown in Figure I. . In the measurement, voltage drop amplitude, initial phase angle, interval time, repetitions etc. can be programed. For instance, the drop amplitude can be set from $0 \%$ to $100 \%$, duration time can be programed from $1 \mathrm{~ms}$ to $5 \mathrm{~min}$ with resolution of $1 \mathrm{~ms}$, drop phase angle can be set from $0^{\circ}$ to $359^{\circ}$ with resolution of $1^{\circ}$ and the output current is programed as 200A. The device can simulate three-phase three-wire (three-phase four-wire) system synchronous voltage sag or a single phase voltage sage, and control the difference of drop time between three phases accurately.

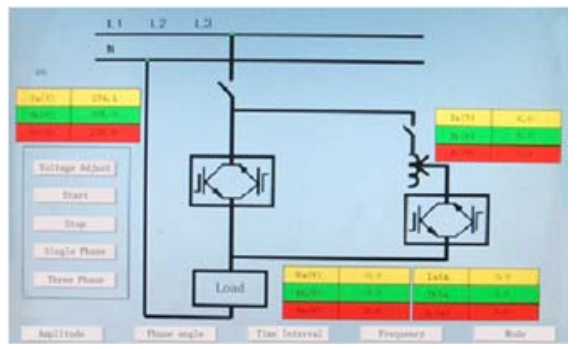

FIGURE I. SCHEMATIC OF VOLTAGE DROP GENERATING DEVICE

The combined measurements can be made by adjusting the following three parameters: dropping amplitude, duration time and falling phase angle. The measurement is repeated three times for each combination. The minimum interval time between two contiguous tests depends on characteristics of the load under test. And the test should be done when the lamp is stable.

The recorded parameters of the lamp include voltage and current waveforms, dropping phase, amplitude, duration time, and restart time for the lamp to recover.

Figure II. shows schematic diagram of a voltage drop. Drop amplitude is defined as the range of the power grid RMS voltage drops, and marked by $1 \%-90 \%$ of the rated value. Drop phase is the initial phase when the voltage start dropping. And duration time means the time while voltage stays low.

\section{B. Measurement Results}

Sodium lamps, metal halide lamps, CFL (Compact Fluorescent Lamp), incandescent lamps, and LED lamps are selected to do the voltage drop test. The startup characteristics and voltage drop response performance of above lamps is shown in TABLE I. . TABLE I. illustrates that LED lamps, incandescent lamps and CFL start up quickly and restart immediately. And on the contrary, sodium lamps and metal halide lamps have relatively poor startup characteristics. They 
take more time to start up, and require about 10 minutes to fully cool down before restarting. However, these lamps are very sensitive to voltage drop.

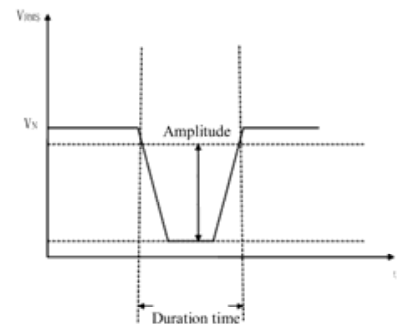

FIGURE II. SCHEMATIC DIAGRAM OF VOLTAGE DROP

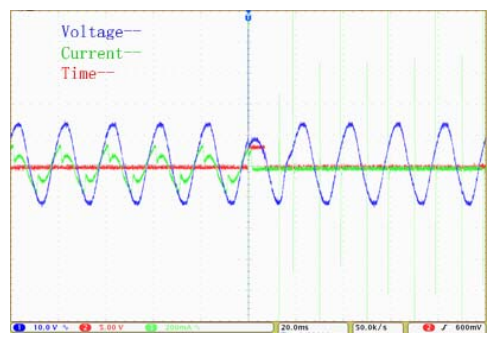

FIGURE III. WAVEFORM OF SODIUM LAMP: VOLTAGE DROPS TO 67\% FOR 6ms (LIGHTS OUT)

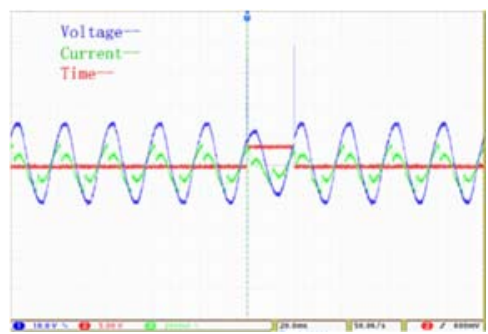

FIGURE IV. WAVEFORM OF SODIUM LAMP: VOLTAGE DROPS TO 81\% FOR 20ms (LIGHTS ON)

TABLE I. THE STARTUP CHARACTERISTICS AND THE VOLTAGE DROPRESPONSE PERFORMANCE OF THE LAMPS

\begin{tabular}{|c|c|c|c|}
\hline Item & Power & $\begin{array}{c}\text { Startup } \\
\text { characteristics }\end{array}$ & $\begin{array}{l}\text { voltage drop } \\
\text { response } \\
\text { performance }\end{array}$ \\
\hline $\begin{array}{l}\text { Sodium Lamp } \\
\text { (Philips) }\end{array}$ & $150 \mathrm{~W}$ & $\begin{array}{l}\text { Cold start, about } \\
5 \text { minutes into } \\
\text { steady state } \\
\text { Restart over } 20 \mathrm{~s} \\
\text { Recover after } \\
\text { about } 3.5 \text { minutes }\end{array}$ & $\begin{array}{c}\text { Keeps on for } 5 \mathrm{~ms} \\
\text { when voltage drops } \\
\text { to zero } \\
\text { When voltage drops } \\
\text { more than } 5 \mathrm{~ms} \text {, } \\
\text { whether it goes out } \\
\text { depends on the } \\
\text { dropping amplitude } \\
\text { and duration time }\end{array}$ \\
\hline $\begin{array}{l}\text { Sodium Lamp } \\
\text { (Philips) }\end{array}$ & $1000 \mathrm{~W}$ & $\begin{array}{l}\text { Cold start, about } 2 \\
\text { minutes into } \\
\text { steady state } \\
\text { Restart about 2-3 } \\
\text { minutes } \\
\text { Recover after } \\
\text { about } 3 \text { minutes }\end{array}$ & $\begin{array}{c}\text { Keeps on for } 22 \mathrm{~ms} \\
\text { when voltage drops } \\
\text { to zero } \\
\text { When voltage drops } \\
\text { more than } 22 \mathrm{~ms} \text {, } \\
\text { whether it goes out } \\
\text { depends on the } \\
\text { dropping amplitude } \\
\text { and duration time }\end{array}$ \\
\hline Metal Halide & $150 \mathrm{~W}$ & Cold start, about 3 & Keeps on for $5 \mathrm{~ms}$ \\
\hline
\end{tabular}

\begin{tabular}{|c|c|c|c|}
\hline $\begin{array}{c}\text { Lamp } \\
\text { (GE) }\end{array}$ & & $\begin{array}{c}\text { minutes into } \\
\text { steady state, } \\
\text { Long time cooling } \\
\text { after goes out } \\
\text { Recover after } \\
\text { 8-10 minutes }\end{array}$ & $\begin{array}{c}\text { when voltage drops } \\
\text { to zero } \\
\text { When voltage drops } \\
\text { more than } 5 \mathrm{~ms} \text {, } \\
\text { whether it goes out } \\
\text { depends on the } \\
\text { dropping amplitude } \\
\text { and duration time }\end{array}$ \\
\hline $\begin{array}{l}\text { Metal Halide } \\
\text { Lamp } \\
\text { (Philips) }\end{array}$ & $\begin{array}{c}150 \mathrm{~W} \\
\text { Double } \\
\text { End }\end{array}$ & $\begin{array}{l}\text { Cold start, about } 3 \\
\text { minutes into } \\
\text { steady state, } \\
\text { Long time cooling } \\
\text { after goes out } \\
\text { Recover after7-9 } \\
\text { minutes }\end{array}$ & $\begin{array}{c}\text { Keeps on for } 8 \mathrm{~ms} \\
\text { when voltage drops } \\
\text { to zero } \\
\text { When voltage drops } \\
\text { more than } 8 \mathrm{~ms} \text {, } \\
\text { whether it goes out } \\
\text { depends on the } \\
\text { dropping amplitude } \\
\text { and duration time }\end{array}$ \\
\hline $\begin{array}{l}\text { Metal Halide } \\
\text { Lamp } \\
\text { (Philips) }\end{array}$ & $250 \mathrm{~W}$ & $\begin{array}{l}\text { Cold start, about } 2 \\
\text { minutes into } \\
\text { steady state, } \\
\text { Long time cooling } \\
\text { after goes out } \\
\text { Recover after } \\
\text { 8-10minutes }\end{array}$ & $\begin{array}{c}\text { Keeps on for } 14 \mathrm{~ms} \\
\text { when voltage drops } \\
\text { to zero } \\
\text { When voltage drops } \\
\text { more than } 14 \mathrm{~ms} \text {, } \\
\text { whether it goes out } \\
\text { depends on the } \\
\text { dropping amplitude } \\
\text { and duration time }\end{array}$ \\
\hline $\begin{array}{l}\text { Metal Halide } \\
\text { Lamp } \\
\text { (Philips) }\end{array}$ & $400 \mathrm{~W}$ & $\begin{array}{l}\text { Cold start about } 3 \\
\text { minutes into } \\
\text { steady state, } \\
\text { Long time cooling } \\
\text { after quench } \\
\text { Recover after } \\
\text { 9-13 minutes } \\
\end{array}$ & $\begin{array}{c}\text { Not off after voltage } \\
\text { dropping to zero for } \\
7 \mathrm{~ms} \text { (visible) } \\
\text { Whether light off or } \\
\text { not after } 7 \mathrm{~ms} \text { is } \\
\text { related to dropping } \\
\text { amplitude and time }\end{array}$ \\
\hline $\begin{array}{l}\text { Metal Halide } \\
\text { Lamp } \\
\text { (Philips) }\end{array}$ & $1000 \mathrm{~W}$ & $\begin{array}{l}\text { Cold start about } 2 \\
\text { minutes into } \\
\text { steady state, } \\
\text { Long time cooling } \\
\text { after quench } \\
\text { Recover after } \\
10-11 \text { minutes }\end{array}$ & $\begin{array}{c}\text { Not off after voltage } \\
\text { dropping to zero for } \\
12 \mathrm{~ms} \text { (visible) } \\
\text { Whether light off or } \\
\text { not after } 12 \mathrm{~ms} \text { is } \\
\text { related to dropping } \\
\text { amplitude and time }\end{array}$ \\
\hline $\begin{array}{l}\text { Metal Halide } \\
\text { Lamp } \\
\text { (Philips) }\end{array}$ & $\begin{array}{l}\text { 1000W } \\
\text { Double } \\
\text { End }\end{array}$ & $\begin{array}{l}\text { Cold start about } 2 \\
\text { minutes into } \\
\text { steady state, } \\
\text { Long time cooling } \\
\text { after quench } \\
\text { Recover after } \\
6-10 \text { minutes }\end{array}$ & $\begin{array}{c}\text { Not off after voltage } \\
\text { dropping to zero for } \\
37 \mathrm{~ms} \text { (visible) } \\
\text { Whether light off or } \\
\text { not after } 37 \mathrm{~ms} \text { is } \\
\text { related to dropping } \\
\text { amplitude and time }\end{array}$ \\
\hline $\begin{array}{c}\text { Energy-saving } \\
\text { Lamp } \\
\text { (OSRAM, } \\
\text { import, } \\
\text { domestic) } \\
\end{array}$ & $\begin{array}{l}18 \mathrm{~W}, \\
42 \mathrm{~W}\end{array}$ & $\begin{array}{l}\text { cold start less than } \\
1 \text { second, } \\
\text { recover instantly } \\
\text { after quench }\end{array}$ & $\begin{array}{l}\text { Visible after voltage } \\
\text { dropping to zero for } \\
5 \mathrm{~ms}\end{array}$ \\
\hline $\begin{array}{l}\text { Incandescent } \\
\text { Lamp }\end{array}$ & $100 \mathrm{~W}$ & $\begin{array}{l}\text { Startup instantly, } \\
\text { recover instantly } \\
\text { after quench }\end{array}$ & $\begin{array}{l}\text { Visible after voltage } \\
\text { dropping to zero for } \\
5 \mathrm{~ms}\end{array}$ \\
\hline $\begin{array}{l}\text { LED Lamp } \\
\text { (OSRAM) }\end{array}$ & $5 \mathrm{~W}$ & $\begin{array}{l}\text { Startup instantly, } \\
\text { recover instantly } \\
\text { after quench }\end{array}$ & $\begin{array}{c}\text { Not off after voltage } \\
\text { dropping to zero for } \\
80 \mathrm{~ms} \\
\text { (Non-visible) }\end{array}$ \\
\hline
\end{tabular}

Figure III. and Figure IV. are waveforms of the sodium lamp when voltage drops to $67 \%$ and $81 \%$ respectively with a duration time of $6 \mathrm{~ms}$. In which we can see that sodium lamps put out $6 \mathrm{~ms}$ later when the voltage drops to $67 \%$, while stay on for $20 \mathrm{~ms}$ when the voltage drops to $81 \%$. Table II-VI are measurement results for typical sodium lamps (SON-T150W, SON-T1000W) and metal halide lamps (HPI-T250W, HPI-T400W, HPI-T1000W) respectively.

According to the measurement results of various kinds and 
different power of gas discharge lamps, it is obvious that the voltage drop response performance of a lamp is related to its power. The higher the power of gas discharge lamp is, the better its voltage drop response performance is.

TABLE II. MEASUREMENT RESULT FOR SODIUM LAMP (SON-T150W)

\begin{tabular}{|c|c|c|c|c|c|c|c|c|c|c|c|c|}
\hline Voltage drop \% & 0 & 69 & 70 & 73 & 76 & 78 & 79 & 80 & 81 & 82 & 83 & 84 \\
\hline Duration time (ms) & 5 & 6 & 11 & 12 & 13 & 14 & 15 & 19 & 21 & 37 & 65 & 400 \\
\hline
\end{tabular}

TABLE III. MEASUREMENT RESULT FOR SODIUM LAMP (SON-T1000W)

\begin{tabular}{|c|c|c|c|c|c|c|c|c|c|c|c|c|c|c|}
\hline Voltage drop \% & 0 & 5 & 10 & 15 & 20 & 25 & 30 & 35 & 40 & 45 & 50 & 55 & 60 & 65 \\
\hline Duration time(ms) & 23 & 25 & 23 & 25 & 24 & 25 & 25 & 24 & 24 & 25 & 26 & 27 & 64 & $\begin{array}{c}\text { Not extinguished in } \\
1 \text { minute }\end{array}$ \\
\hline
\end{tabular}

TABLE IV. MEASUREMENT RESULT FOR METAL HALIDE LAMP (HPI-T250W)

\begin{tabular}{|c|c|c|c|c|c|c|c|c|c|c|c|c|c|c|c|}
\hline Voltage drop \% & 0 & 5 & 10 & 15 & 20 & 25 & 30 & 35 & 40 & 45 & 50 & 60 & 65 & 75 & 80 \\
\hline Duration time(ms) & 15 & 14 & 15 & 13 & 14 & 14 & 13 & 14 & 12 & 18 & 13 & 24 & 25 & $\begin{array}{c}120 \\
\text { Not extinguished in } \\
200 \mathrm{~ms}\end{array}$ \\
\hline
\end{tabular}

TABLE V. MEASUREMENT RESULT FOR METAL HALIDE LAMP (HPI-T400W)

\begin{tabular}{|c|c|c|c|c|c|c|c|c|c|c|c|c|}
\hline Voltage drop \% & 0 & 15 & 20 & 30 & 35 & 40 & 45 & 50 & 55 & 60 & 65 & 70 \\
\hline Duration time(ms) & 8 & 11 & 13 & 14 & 14 & 15 & 15 & 14 & 21 & 25 & 42 & $\begin{array}{c}\text { Not extinguished in } \\
380 \mathrm{~ms}\end{array}$ \\
\hline
\end{tabular}

TABLE VI. MEASUREMENT RESULT FOR METAL HALIDE LAMP (HPI-T1000W)

\begin{tabular}{|c|c|c|c|c|c|c|c|c|c|c|c|c|c|c|c|}
\hline Voltage drop \% & 0 & 5 & 10 & 15 & 20 & 25 & 30 & 35 & 40 & 45 & 50 & 55 & 60 & 65 & 70 \\
\hline Duration time(ms) & 13 & 14 & 17 & 17 & 18 & 17 & 19 & 19 & 18 & 23 & 25 & 28 & 41 & 103 & 700 \\
\hline
\end{tabular}

\section{LAMP COMPENSATION FOR VOLTAGE DROP}

\section{A. Principle of Compensation Device}

According to above results of the lamp test under a voltage drop, a compensation device for lamps under voltage drop is proposed in this paper. A capacitor is adopted in the compensation device for storing energy. When the grid voltage is operating normally, the lamp is powered by the grid and the capacitor can be charged from the grid by a rectifier. When the power grid voltage drops to $60 \%$ of the rated value, the energy stored in the capacitor will go through an inverter circuit, changing the voltage to AC $220 \mathrm{~V}$ and outputting to the lamp. The lamp will be powered by the compensation device.

A DSP is adopted in the system to monitor the real-time power grid voltage and control the circuit. Figure V. illustrates the structure diagram of the compensation device.

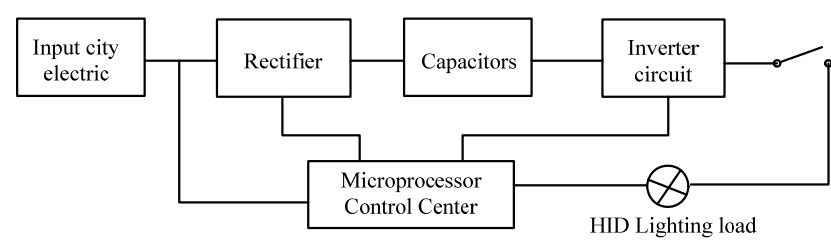

FIGURE V. STRUCTURE DIAGRAM OF COMPENSATION DEVICE
Figure VI. is the main circuit diagram of the compensation device. The structure of the inverter is a single phase bridge. And an electrolytic capacitor is adopted as the energy-storing device in DC side of the inverter, supplying voltage in DC side $\left(u_{d}\right)$. While the power grid voltage operating normally, the bidirectional thyristor VT1 turns on. And when the power grid voltage drops to less than $40 \%$, the capacitor in DC side is charged though the anti-parallel diodes of IGBT and the inductance, the current through VT1 breaks and isolates the load from the power grid. Meanwhile, VT2 turns on and the inverter outputs AC voltage for the load.

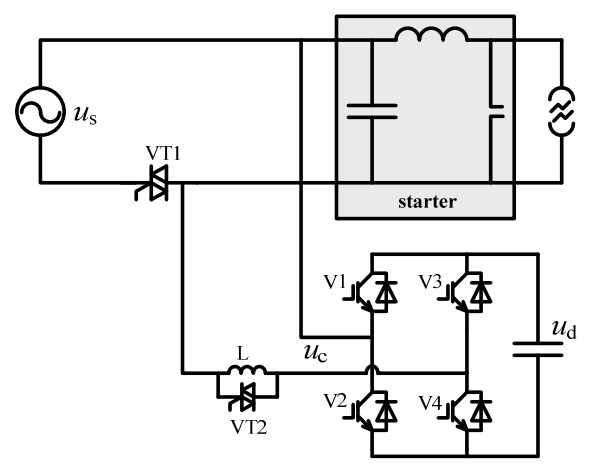

FIGURE VI. THE MAIN CIRCUIT DIAGRAM OF THE COMPENSATION DEVICE 
Figure.7 shows the control circuit diagram of the compensation device. The control circuit is based on the DSP digital-analog hybrid structure. The central processing unit DSP samples the power grid voltage (us) for switching judgment, and samples the voltage in DC side $\left(u_{d}\right)$ to control the effective value of output voltage. The PWM unit of DSP outputs four high frequency driving signals to the 4 IGBTs in the inverter bridge and two switching signals to the 2 thyristor switches. The power for circuit control part supplies in two ways. When the power grid operates normally, it is powered by rectifying step-down power grid voltage. And when the power grid is disconnected for abnormal voltage, it is powered by the divided DC voltage.

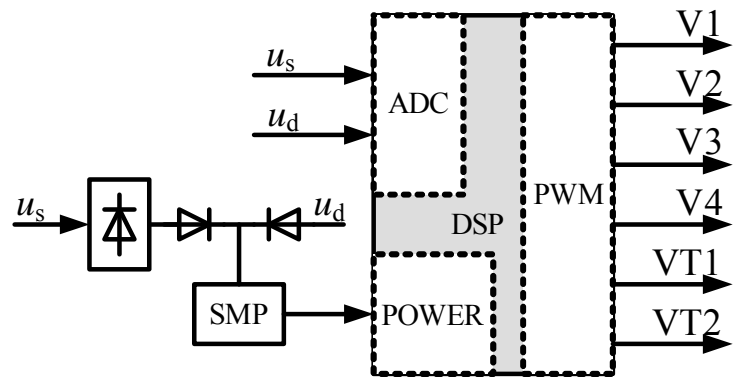

FIGURE VII. CONTROL CIRCUIT DIAGRAM OF THE COMPENSATION DEVICE

\section{B. Results}

According to the test, the lamp will quench when the power grid voltage drops to $70 \%$ of its rated value considering a $400 \mathrm{~W}$ metal halide lamp as the load. In this case, the threshold voltage can be set as $70 \%$ of the rated value to switch. The device will switch when the grid voltage drops to less than $154 \mathrm{~V}$. Supposing the maximum input voltage of the lamp is $120 \%$ of the rated value, which is $220 * 1.2=264 \mathrm{~V}$

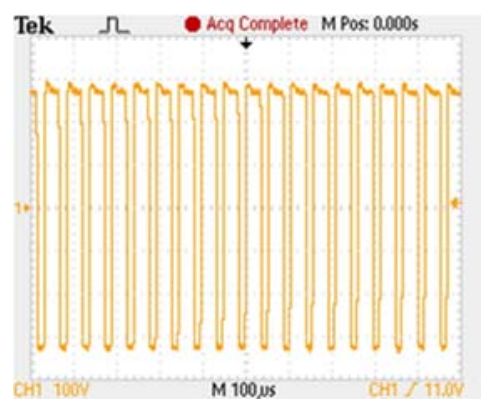

FIGURE VIII. VOLTAGE WAVEFORM OF THE INVERTER OUTPUT

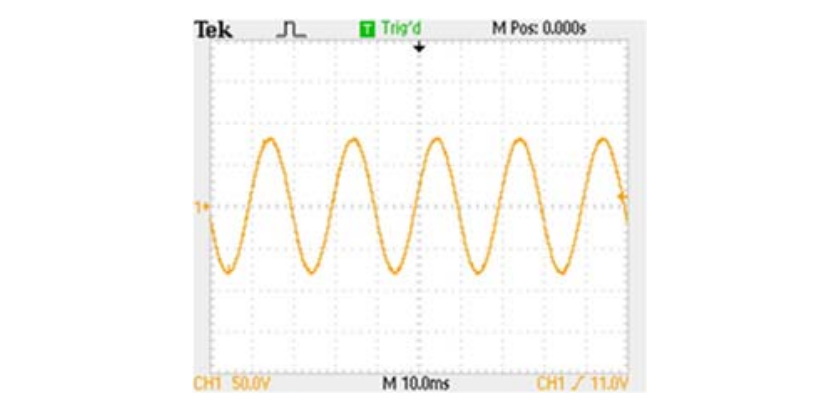

FIGURE IX. LOAD VOLTAGE WAVEFORM OF THE INVERTER OUTPUT
Set the duration time to $100 \mathrm{~ms}$ when the grid is disconnected, which is also the time that the grid backup power supply needs to secondary switch. The following formula shows the calculation for energy storage capacitor.

$$
C=\frac{2 P t}{V 1^{2}-V 2^{2}}=\frac{2 * 400 * 100}{264^{2}-154^{2}}=1.74 m F=1740 \mu F
$$

In practical applications, taking into account a certain margin, select two $400 \mathrm{~V} / 1000 \mu \mathrm{F}$ capacitor. Figure VIII. illustrates the voltage waveform of the inverter output. And Figure IX. shows the load voltage waveform of the inverter output. Connect the compensation device to a $400 \mathrm{~W}$ metal halide lamp. When the grid is disconnected for $100 \mathrm{~ms}$, the lamp stays on. And when the grid voltage drops to $60 \%$, the lamp stays on over $10 \mathrm{~s}$.

\section{CONCLUSION}

In this paper, several typical lamps from the market are selected to do the voltage drop test. The experiment shows that metal halide lamps, sodium lamps and other gas discharge lamps are relatively sensitive to voltage, and have poor starting characteristics. Finally, according to the test results, this paper presents a compensation device for a single lamp to ensure that the lamp can be compensated rather than extinguished when the power grid voltage drops or power off suddenly.

\section{REFERENCE}

[1] M. F. Mcgranaghan, D. R. Mueller and M. J. Samotyj, "Voltage sags in industrial systems," IEEE Trans. Ind. Appl., vol.29, no.2, p.397, 1993.

[2] H. Zhang, B. Wang and T. Tian, "Research on dynamic voltage restorer based on variable structure control theory," Electrical Measurement \& Instrumentation, vol.48, no.550, pp.42-46, 2011.

[3] J. Lamoree, D. Mueller, P. Vinett and W. Jones, "Voltage sag analysis case studies," in IEEE Industrial and Commercial Power Systems Technical Conference, 1993, pp.55-61.

[4] X. Xiao, X. He and B. Chen, "Research on a dynamic voltage restorer based on distribution network voltage sag," Electric Switcher, vol.49, no.3, pp.23-25, 2011.

[5] B. Wang, D. Pan and B. Xu, "Analysis of voltage sags in distribution system,” Power System Technology, vol.28, no.2, pp.56-59, 2004.

[6] L. Zhang, H. Meng and G. Wang, "The design of starting circuit of HID lamp," Journal of Agricultural University of Hebei, vol.32, no.5, pp.119-123, 2009.

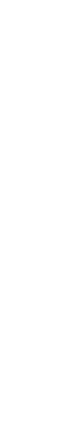

